\title{
Analisis Penerapan Fatwa MUI Wisata Halal (Studi Kasus Hotel Syariah Medan)
}

\author{
Riyan Pradesyah ${ }^{1 *}$, Khairunnisa ${ }^{2}$ \\ ${ }^{1}$ Universitas Muhammadiyah Sumatera Utara \\ ${ }^{2}$ Universitas Islam Negeri Sumatera Utara \\ ${ }^{1}$ Email: rriyanpradesyah@yahoo.com \\ ${ }^{2}$ Email: khairunnisa.hd@gmail.com
}

\begin{tabular}{l} 
Abstract \\
\hline The purpose of this study was to find out whether sharia \\
hotels in the Medan city had implemented the MUI Fatwa, \\
related to halal tourism. The method used in the study is a \\
qualitative method, comparing the theory with the events in \\
the field. The results obtained, that sharia hotels in the city \\
of Medan have implemented regulations issued by the MUI \\
on halal tourism, which is regulated in No.108 / DSN-MUI / \\
X / 2016. This is shown by the facilities of places of worship \\
such as mushalah, the unavailability of food and drinks, the \\
pornography sites that are on the internet access, not \\
receiving guests who are not Muslims. \\
Keywords: Fatwa MUI Halal Tourism, Sharia Hotels \\
\hline
\end{tabular}

\section{Abstrak}

Tujuan penelitian ini adalah untuk mengetahui apakah hotel syariah di kota Medan telah menerapkan Fatwa MUI, terkait dengan pariwisata halal. Metode yang digunakan dalam penelitian ini adalah metode kualitatif, membandingkan teori dengan peristiwa di lapangan. Hasil yang didapat, bahwa hotel syariah di kota Medan telah menerapkan peraturan yang dikeluarkan oleh MUI pada pariwisata halal, yang diatur dalam No.108 / DSN-MUI / X / 2016. Hal ini ditunjukkan oleh fasilitas tempat ibadah seperti seperti mushalah, tidak tersedianya makanan dan minuman, situs pornografi yang ada di akses internet, tidak menerima tamu yang bukan Muslim.

Kata Kunci: Fatwa MUI Pariwisata Halal, Hotel Syariah

\section{A. Pendahuluan}

\subsection{Latar Belakang}

Pariwisata merupakan salah

suatu komponen dalam pembangun

sebuah perekonomian yang ada pada
Artikel Info

Received:

17 September 2018

Revised:

18 October 2018

Accepted:

23 November 2018 


\section{INTIQAD: JURNAL AGAMA DAN PENDIDIKAN ISLAM}

ISSN 1979-9950 (print) || ISSN 2598-0033 (online), http://jurnal.umsu.ac.id/index.php/intiqad

DOI: https://doi.org/10.30596/intiqad.v10i2.1986

Published December 2018

pariwisata di dunia yang mulai mengembangkan sektor wisata, mulai dari negara maju hingga negara yang perekonomian negaranya masih mengalami pengembangan atau peningkatan. $\mathrm{Di}$ Indonesia, perkembangan wisata dari tahun ke tahunnya telah mengalami perkembangan, banyaknya pengunjung yang terjadi, menjadi tempat wisata yang ada di Indonesia, terus mengalami pembenahan, mulai dari tempat wisatanya sendiri, makanan, fasilitas yang ada seperti penginapan, kenyamanan tempat, hingga pada hiasanhiasan yang ada di tempat wisata itu sendiri. Kontribusi sektor wisata Indonesia terhadap negara kini telah mengalami peningkatan dari 10\% menjadi $17 \%$ dari total ekspor barang dan jasa di Indonesia, dari penyumbang devisa tersebesar ke 5, kini meningkat menjadi penyumbang devisa terbesar ke 4 , dengan penghasilan devisa sebesar 10 miliar USD. Sementara itu kontribusi secara langsung terhadap PDB sudah mencapai $3,8 \%$ dan jika memperhitungkan efek penggandanya, kontribusi wisata pada PDB mencapai sekitar 9\%. Penyerapan tenaga kerja di sektor ini juga sudah mencapai 10,18 juta orang atau $8,9 \%$ dari total jumlah pekerja sehingga pariwisata merupakan salah satu pencipta tengaa kerja terbesar ke empat.

Sektor wisata yang digadanggadang mampu meningkatkan perekonomian, kini telah menjadi nyata, dapat dilihat dari peningkatan atau penyumbang devisa terbesar yang kini berada pada posisi empat. Perkembangan wisata di indonesia, kini mulai merambah ke daerah-daerah yang ada di Indonesia. Perkembangan wisata ini merupakan suatu yang menggebirakan bagi warga Indonesia dan pemerintah. Sebab, semakin berkembangnya sektor wisata yang ada di daerah-daerah, maka semakin cepat pula pertumbuhan perekonomian yang ada pada suatu daerah tersebut. Untuk itu, perkembangan wisata ini perlu untuk terus di tingkatkan, sehingga masyarakat yang ada di daerah sekitar dapat meningkatkan perekonomian mereka, dengan cara membuka suatu usaha, mulai dari usaha makanan, jajanan, tempat berteduh, sampai pada penginapan yang ada di sekitar tempat wisata.

Wisata syariah merupakan salah satu trend baru dalam dunia pariwisata 


\section{INTIQAD: JURNAL AGAMA DAN PENDIDIKAN ISLAM}

ISSN 1979-9950 (print) || ISSN 2598-0033 (online), http://jurnal.umsu.ac.id/index.php/intiqad

DOI: https://doi.org/10.30596/intiqad.v10i2.1986

Published December 2018

saat ini. Di negara Indonesia, penerapan wisata syariah kini mulai dikembangkan, hal ini dapat kita lihat dari banyaknya tempat-tempat wisata yanga da di indonesia menggunakan prinsip syariah, baik itu dimulai dengan wisatawannya, biro perjalanan, pengusaha pariwisata, pemadu wisata, terapis dan hotel. Negara Indonesia, juga pernah mendapatkan penghargaan dunia, atas kemenangannya dalam ivent "The World halal Travel Summit \& Exhibition 2015" di dalam ivent ini, Indonesia berhasil mendaptkan tiga penghargaan sekaligus, yaitu penghargaan "World Best Family Friendly Hotel, World Halal Honneymoon Destination, dan World Best Halal Tourism Destination." (Ade, 2016). Hal ini tentu saja menjadi salah satu daya tarik bagi negara Indonesia terhadap negara lain, untuk menarik para touris berdatangan kenegara Indonesia. Setelah mendapatkan tiga penghargaan tersebut, kini negara Indonesia juga telah mengembangkan wisata halal, baik itu dari tempat wisatanya, makanan, biro perjalanan, maupun tempat penginapan atau hotel syariah.

Sumatera Utara, merupakan salah satu propinsi yang kini telah mengembangkan konsep wisata halal itu sendiri. Beberapa tempat wisata, kini mulai dicoba dalam penerapan konsep wisata halal. Di dalam hal ini, wisata halal yang mulai berkembang di propisi Sumatera Utara adalah Hotel syariah. Hotel syariah merupakan salah satu dari Indikator tentang wisata halal, yang telah diatur oleh Fatwa MUI No.108/DSNMUI/X/2016, di dalam fatwa tersebut, Majelis Ulama Indonesia mengutarakan tentang peraturan yang harus diberlakukan pada hotel syariah, diantaranya adalah tidak bolehnya menyediakan akses pornografi dan tidak kesusilaan, tidak boleh menyediakan hiburang yang mengarah pada kemusrikan dan pornografi, makan dan minuman yang ada harus halal, menyediakan tempat ibadah, pengelola wajib menggunakan pakaian yang sesuai dengan syariah, dan hotel syariah wajib menggunakan jasa Lembaga Keuangan Syariah dalam melakukan pelayanan. Dari indikator ini, peneliti ingin melihat, sudah sejauh mana penerapan yang dilakukan oleh hotel syariah, yang ada di kota Medan, Sumatera Utara, bila dilihat dari indikator-indikator yang dikeluarkan oleh Fatwa Majelis Ulama Indonesia, tentang penyelenggaraan hotel secara syariah. Karena dalam hal ini, masih 


\section{INTIQAD: JURNAL AGAMA DAN PENDIDIKAN ISLAM}

ISSN 1979-9950 (print) || ISSN 2598-0033 (online), http://jurnal.umsu.ac.id/index.php/intiqad

DOI: https://doi.org/10.30596/intiqad.v10i2.1986

Published December 2018

banyak para masyarakat, yang hanya menerapkan nama "Syariah" saja, tanpa harus menerapkan prinsip syariah itu sendiri. Jadi berdasarkan permasalahan inilah, penulis ingin lakukan pengamatan lebih lanjut dan mengangkat permasalahan penelitian menggunakan judul “ Analisis Penerapan Fatwa MUI Wisata Halal (Studi Kasus Hotel Syariah Medan).

\subsection{Rumusan Masalah}

Berdasarkan uraian latar belakang diatas, disusunlah beberapa masalah penelitian, sebagai berikut:

1.2.1. Bagaimana ketentuan yang berlaku pada hotel syariah di Kota Medan?

1.2.2. Apakah hotel syariah yang ada di Kota Medan, sudah menerapkan Fatwa MUI No.108/DSN-MUI/X/2016, tentang pedoman penyelenggaraan pariwisata berdasarkan prinsip syariah?

\subsection{Batasan Masalah}

Fatwa MUI No.108/DSNMUI/X/2016, tentang pedoman penyelenggaraan pariwisata berdasarkan prinsip syariah, membahas tentang semua sektor pariwisata, mulai dari tempat penginapan atau hotel, tempat wisatanya, destinasi wisata, spa, sauna dan massage, biro perjalanan, sampai pemandu wisata. Untuk itu disini peneliti membatasi masalah tersebut, yaitu hanya pada penerapan Fatwa MUI tentang hotel syariah.

\subsection{Tujuan Penelitian}

Merupakan suatu yang harus dicapai dalam penelitian, untuk itu, tujuan penelitian adalah sebagai berikut:

$$
\begin{aligned}
& \text { 1.4.1. Untuk mengetahui dan } \\
& \text { menganlisis ketentuan yang } \\
& \text { berlaku pada hotel syariah di Kota } \\
& \text { Medan. }
\end{aligned}
$$

\subsubsection{Untuk menganalisis penerapan fatwa MUI wisata halal, terhadap hotel syariah di Kota Medan}

\section{B. Tinjauan Pustaka}

\section{Kajian Teori}

Hotel syariah merupakan suatu hotel yang mempunyai operasional sesuai dengan prinsip syariah. Perkembangan hotel syariah di Indonesia dari tahun ketahunnya terus mengalami peningkatan yang signifikan, hal ini terlihat dari banyaknya hotel syariah yang kini mulai di gandrungi oleh masyarakat, bukan hanya itu saja, hotel syariah kini juga menjadi salah satu rujukan bagi para wisatawan yang ingin 


\section{INTIQAD: JURNAL AGAMA DAN PENDIDIKAN ISLAM}

ISSN 1979-9950 (print) || ISSN 2598-0033 (online), http://jurnal.umsu.ac.id/index.php/intiqad

DOI: https://doi.org/10.30596/intiqad.v10i2.1986

Published December 2018

melakukan perjalanan. Pariwisata merupakan salah satu hal yang kini mulai dikembangkan oleh negaranegara. Sebab, dengan adanya objek wisata, maka negara dapat meningkatkan perekonomian dan pendapatan yang ada pada suatu negara. Bukan hanya itu saja, adanya objek wisata yang menarik, maka akan menarik para wisatawan untuk berkunjung ke negara tersebut. Dari sinilah devisa negara akan terus mengalami peningkatan. Apabila wisatawan yang ada, terus mengalami peningkatan, perihal untuk mengunjungi objek wisata yang ada pada suatu negara. Bukan hanya itu saja, pariwisata juga merupakan salah satu penyumbang pajak paling tersebesar, dari pajak inilah negara dapat membangun atau membenahi negaranya dengan baik. Menurut Undang Undang No. 10/2009 tentang Kepariwisataan, yang dimaksud dengan pariwisata adalah berbagai macam kegiatan wisata yang didukung oleh berbagai fasilitas serta layanan yang disediakan masyarakat, pengusaha, Pemerintah dan Pemerintah Daerah. ${ }^{1}$

Berkembangnya hotel syariah yang ada di Indonesia, tentu tidak Pariwisata terlepas dari yang namanya pariwisata, atau objek wisata yang ada di Indonesia. Perkembangan objek wisata yang ada pada negara, juga akan mempengaruhi pendapatan negara. Hal tersebut terkait dengan, semakin banyaknya wisatawan asing yang datang kenegara tersebut, maka semakin banyak pula pendapatan yang di dapat oleh negara. Jika pendapatan negara semakin meningkat, maka infrastruktur yang ada di negara tersebut, akan semakin baik. Tujuan inilah yang salah satunya ingin dicapai oleh negara, memebanhi insfrastruktur yang ada pada negara, apabila pendapatan negara telah mengalami peningkatan. Bukan hanya itu saja, peningkatan perekonomian juga akan terjadi, apabila objek wisata yang ada pada negara menjadi salah satu hal yang paling menarik dibanding dengan negara-negara lain. Pertumbuhan perekonomian ini akan selalu mengalami peningkatan, terlebih pada penduduk atau masyarakat yang bermukin disekitar tempat wisata tersebut. Penduduk yang ada disekitar tentu saja akan membuat suatu usaha, baik itu usaha makanan khas pada daerah tersebut, mapun usaha travel atau perjalanan menuju ketempat wisata. 


\section{INTIQAD: JURNAL AGAMA DAN PENDIDIKAN ISLAM}

ISSN 1979-9950 (print) || ISSN 2598-0033 (online), http://jurnal.umsu.ac.id/index.php/intiqad

DOI: https://doi.org/10.30596/intiqad.v10i2.1986

Published December 2018

Biasanya, tempat wisata selalu dikaitkan dengan tempat penginapan yang ada, objek wisata yang baik, akan di dukung dengan tempat penginapan yang nyaman dan tidak jauh dari objek tersebut. Tempat penginapan seperti hotel atau motel, biasa banyak disajikan oleh masyarakat, terkait mereka juga melihat peluang bisnis yang ada pada daerah wisata tersebut. Untuk itu, inilah yang dapat dikatakan sebagai "Pariwisata dapat meningkatkan perekonomian". Dari sinilah masyarakat yang ada disekitar akan meningkatkan perekonomian mereka, dengan membaca atau mengalisis peluang-peluang yang di dapat pada wisata tersebut.

Pariwisata yang semakin marak tidak lain dikarenakan adanya fasilitas akomodasi yang disebut dengan Hotel, yang menjamin para wisatawan untuk beristirahat dengan segala kelengkapan fasilitas yang disediakan. Hotel merupakan salah satu tempat atau bangunana yang disediakan oleh sekolompok orang atau lebih, untuk tempat penginapan. Sedangkan hotel menurut surat keputusan menteri perhubungan RI No., PM 10/PW301/Phb. 77, tanggal 12 Desember 1997, hotel adalah suatu bentuk akomodasi yang dikelola secara komersil, disediakan bagi setiap orang untuk memperoleh pelayanan penginapan, beriku makan dan minum. ${ }^{2}$

Sedangkan hotel menurut Surat kepetusan Menparpostel No.KM 34/Hk 103/MPPT-87, hotel merupakan suatu jenis akomondasi yang mempergunakan sebagian atau seluruh bangunana untuk menyediakan jasa penginapan, makan dan minum serta jasa lainnya bagi umu, yang dikelola secara komersil serta memenuhi ketentuan persyaratan yang ditetapkan dalam keputusan pemerintah. (Menteri Pariwisata, Pos, dan Telekomunikasi No.KM 34/Hk 103/MPPT-87. Pengertian Hotel). Hotel adalah sebuah bangunan yang disediakan kepada publik secara komersial untuk para tamu yang ingin mendapat pelayanan menginap, makanan atau minuman dan pelayanan lainnya. $^{3}$

Pada tempat wisata, biasanya terdapat losmen atau tempat penginapan yang hampir mirip dengan hotel. Hanya saja losmen tidak selengkap dengan

${ }^{2}$ Surat Keputusan Menteri Perhubungan R.I No. PM 10/PW - 301/Phb. 77, tanggal 12 Desember 1977.

3 Bagyono Ludfi Urbani, Dasar-dasar Housekeeping dan Loundry Hotel, (Yogyakarta : Adicita Karya Nusa, 2003), h. 35 


\section{INTIQAD: JURNAL AGAMA DAN PENDIDIKAN ISLAM}

ISSN 1979-9950 (print) || ISSN 2598-0033 (online), http://jurnal.umsu.ac.id/index.php/intiqad

DOI: https://doi.org/10.30596/intiqad.v10i2.1986

Published December 2018

fasilitas yang dimiliki oleh hotel. Di dalam hal ini, juga ada tempat penginapan yang juga disebut dengan kost, atau tempat penginapan yang lebih kecil dibanding dengan losmen, lagilagi dalam hal ini yang berbeda juga hanya fasilitas yang tersedia di dalamnya. Dan kedua tempat penginapan tersebut, juga sering dijumpai atau ditemui pada sekitaran tempat wisata.

Di dalam hal ini, tempat yang paling mewah yang ada di dekat tempat wisata biasanya adalah hotel, tentunya memiliki fasilitas yang lengkap, dengan harga yang tinggi. Hotel juga merupakan salah stau tempat bagi rujukan para pengunjung, selian harganya yang tinggi juga menyediakan keamanan, serta kenyamanan dalam melakukan istirahat. Hotel memiliki banyak macam, yang tentunya dapat dipilih oleh konsumen atau pemakain hotel, ada hotel ekonomis untuk yang memiliki dan pas-pasan, ada uga hotel yang mewah untuk orangorang yang memiliki uang yang cukup.

Untuk konsep wisata halal, hotel juga diatur di dalam peraturan yang ditetapkan oleh Majelis Ulama Indonesia, di dalam hal ini hotel mempunyai landasan dalan Q.S.Al Maidah ayat 90-91 :

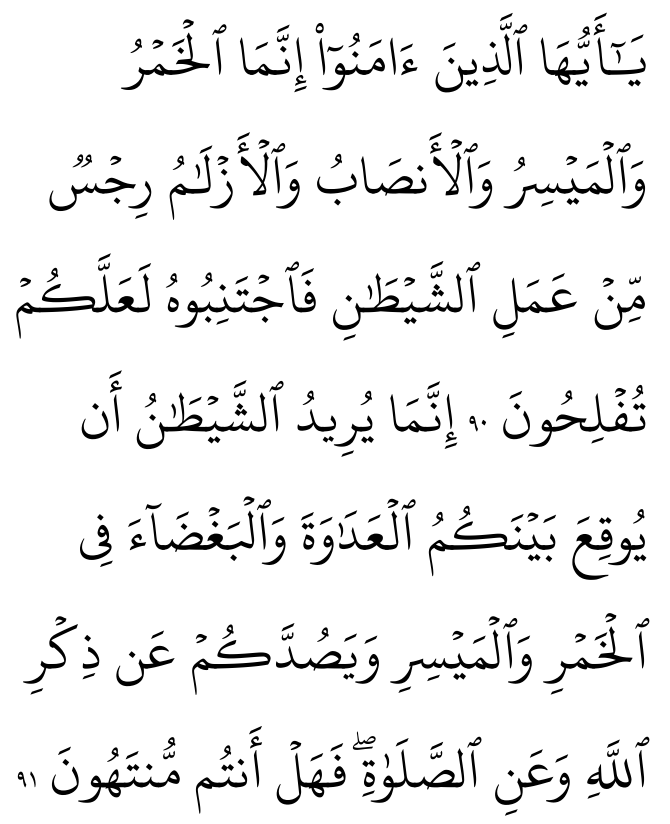

"Hai orang-orang yang beriman, sesungguhnya (meminum) khamar, berjudi, (berkorban untuk) berhala, mengundi nasib dengan panah, adalah termasuk perbuatan syaitan. Maka jauhilah perbuatanperbuatan itu agar kamu mendapat keberuntungan"

"Sesungguhnya syaitan itu bermaksud hendak menimbulkan permusuhan dan kebencian di antara kamu lantaran (meminum) khamar dan berjudi itu, dan menghalangi kamu dari mengingat Allah dan sembahyang; maka berhentilah kamu (dari mengerjakan pekerjaan itu)",

Tempat penginapan syariah atau hotel syariah, merupakan salah stau hotel yang operasionalnya menggunakan 


\section{INTIQAD: JURNAL AGAMA DAN PENDIDIKAN ISLAM}

ISSN 1979-9950 (print) || ISSN 2598-0033 (online), http://jurnal.umsu.ac.id/index.php/intiqad

DOI: https://doi.org/10.30596/intiqad.v10i2.1986

Published December 2018

prinsip syariah. Dimana dalam hotel tersebut tidak menjalankan apa yang telah dilarang oleh Al-Quran dan hadist, seperti tidak menjaul minuman haram, tidak membuka bar untuk hal yang tidak dibolehkan dalam alquran, tidak menyediakan tempat untuk maksiat, dan tidak menjaul hal-hal yang diharamkan, baik makanan maupun minuman.

\section{Metode Penelitian}

\subsection{Pendekatan Yang Digunakan}

Pendekatan penelitian yang digunakan dalam penelitian ini menggunakan kualitatif, diaman peneliti akan mendeskripsikan hasil wawancara dan observasi kepada objek, sehingga akan dapat ditarik satu kesimpulan yang nanti merupakan jawaban atas pertanyaan-pertanyaan dari penelitian.

\subsection{Informan}

$$
\text { Informan merupakan objek }
$$

pada penelitian. Dalam penelitian ini menggunakan teknik purpose sampling, dalam hal ini objek yang diambil pada penelitian yang dilakukan adalah hotel syariah kota Medan.

\subsection{Proses Pengumpulan Data}

Proses pengumpulan data yang dilakukan peneliti dengan cara wawancara, dan observasi. Di dalam wawancara peneliti akan mewawancarai bagian bidang kepala perhotelan yang ada di masing-masing hotel dan wakilnya. Untuk mengetahui jawaban dari wawancara yang didapat, maka peneliti akan membandingkan antara jawaban satu dengan jawaban lainnya dalam satu hotel yang sama, maka teknik ini biasanya disebut dengan teknik melihat keabsahan data.

Kemudian selain wawancara peneliti juga akan melakukan obeservasi, dimaan dalam obeservasi ini, peneliti akan mengamati tentang keadaan hotel sebut, terkait dengan desain yang dimiliki, tata letak kamarmandi, mushalah, dan lain sebagainya yang telah diatur dalam Majelis Ulama Indonesia, atau MUI

\subsection{Teknik Analisa Data}

Teknik analisa data dalam penelitian ini menggunakan prosedur yang dikemukakan oleh Miles and Huberman dengan langkah-langkah sebaai berikut: ${ }^{4}$

1. Reduksi Data

${ }^{4}$ Miles, M.B. \& Huberman, Qualitative Data Analysis: A Sourcebook Of New Methods, (Thousand Oaks, CA: Sa, 1994), h. 21-25 


\section{INTIQAD: JURNAL AGAMA DAN PENDIDIKAN ISLAM}

ISSN 1979-9950 (print) || ISSN 2598-0033 (online), http://jurnal.umsu.ac.id/index.php/intiqad DOI: https://doi.org/10.30596/intiqad.v10i2.1986

Published December 2018

Reduksi data adalah proses sebelumnya maka dapat diambil
seleksi, memfokuskan data, kesimpulan secara baku dan dimuat menyederhanakan data dan abstraksi dalam laporan hasil penelitian. data serta kategori data yang sudah ada juga termasuk catatan lapangan, dimana proses ini berlangsung sepanjang proses pengumpulan data. Reduksi data mempertegas, memperpendek, membuat fokus analisis sedemikian rupa sehingga kesimpulan dapat dilakukan.

2. Penyajian Data

Penyajian data sebagai langkah menyusun informasi yang telah direduksi untuk menarik kesimpulan dan mendeskripsikan langkah-langkah berikutnya. Data penelitian akan disajikan dalam bentuk matriks, agar mudah dilihat dan dimengerti secara kompleks.

\section{Penarik Kesimpulan dan Verifikasi Data \\ Berdasarkan hasil reduksi data} dan penyajian data maka peneliti akan melakukan penarikan kesimpulan sementara, sebelum ditemukannya bukti-bukti yang kuat dari verifikasi data dilapangan. Verifikasi data dilakukan dengan langsung terjun ke lapangan untuk mengumpulkan data. Jika terjadi kesamaan data dengan data

\section{Hasil Analisis dan Pembahasan}

\subsection{Analisis Data}

Perkembangan pariwisata halal yang ada di Sumatera Utara telah mengalami peningkatan, salah satu hal yang dapat kita lihat dari pertumbuhan tersebut adalah, meningkatnya jumlah hotel syariah atau hotel Islam yang ada di Sumatera Utara, khususnya di Meda. Di dalam penelitian yang dilakukan oleh peneliti, telah melihat beberapa hotel syarih atau hotel Islam yang ada di Medan, diantaranya adalah Hotel Islam Aceh House, Hotel Transit Syariah, dan Hotel Saudara Syariah. Hotel-hotel ini tentunya menerapkan prinsip syariah pada operasionalnya, maka untuk itu, disini peneliti telah mendapatkan data, atas hasil wawancara yang peneliti lakukan, adapun hasil yang di dapat peneliti tentang hotel-hotel syariah yang ada di Kota Medan adalah sebagai berikut :

1. Hotel ABC

Adapun hasil wawancara yang di dapatkan oleh peneliti, terkait dengan Dewan Syariah Nasional, tentang 


\section{INTIQAD: JURNAL AGAMA DAN PENDIDIKAN ISLAM}

ISSN 1979-9950 (print) || ISSN 2598-0033 (online), http://jurnal.umsu.ac.id/index.php/intiqad

DOI: https://doi.org/10.30596/intiqad.v10i2.1986

Published December 2018

standart hotel syariah adalah sebagai berikut:

a. Pertama peneliti menanyakan tentang fasilitas yang tersedia pada Hotel ABC. Adapun pasilitas yang disebutkan berupa, wifi, parkir, sarapan, restoran, $\mathrm{AC}$, dan ruang bebas asap rokok.

b. Kemudian pertanyakan kedua peneliti tentang jaringan yang ada di hotel tersebut seperti wifi, karena ini tekait dengan pornografi. Maka jawaban dari manajer hotel, bahwa mereka menggunakan wifi dengan jaringan telkomsel, jadi jarangan ini bisa memprotek hal-hal yang berbau pornografi, maka untuk itu perusahaan bekerjasama dengan telkomsel, untuk wifi yang ada pada hotel.

c. Kemudian pertanyaan selanjutnya mengenai makanan dan minuman yang ada pada hotel. Makanan dan minuman yang ada pada Hotel ABC memiliki standart, diantaranya adalah memasak makanan yang halal. Hotel ini juga tidak menyediakan makana dan minuman yang haram, karena apabila didapatkannya kostumer atau pelayan membawa makanan atau minuman haram, maka akan dikenakan sangsi oleh pihak hotel, dna tentunya akan dibawa kepada jalur hukum.

d. Pertanyaan selanjutnya yaitu tentang adanya masjid atau mushalah. Tekait hal mushalah atau masjid, hotel $\mathrm{ABC}$ hanya menyediakan mushalah saja, karena apabila mereka menyediakan masjid, maka butuh ruang yang besar, dan tentu saja akan memakan tempat yang tersedia. Di mushalah juga terdapat tempat wudhu, bagi siapapun yang ingin melaksanakan shalat.

e. Hotel $\mathrm{ABC}$ juga memiliki standart peraturan yang ketata, terkait dengan pakaian karyawannya. Bahwa, seorang perempuan harus menggunakan pakaian yang menutupi auratnya, seperti menggunakan jilbab panjang, sampai pada pakaian yang longgar, atau tidak menampakan aurat yang dimiliki. Kemudian, customer servis harus melayani tamu dnegan sopan, mengucapkan salam ketika tamu masuk dan keluar. Kariyawan juga diperbolehkan 


\section{INTIQAD: JURNAL AGAMA DAN PENDIDIKAN ISLAM}

ISSN 1979-9950 (print) || ISSN 2598-0033 (online), http://jurnal.umsu.ac.id/index.php/intiqad DOI: https://doi.org/10.30596/intiqad.v10i2.1986

Published December 2018

melaksanakan shalat, tetapi dengan cara bergantian dengan teman yang lainnya.

f. Hotel ABC, juga memiliki kerjasama dengan dengan bank aceh, terkait dengan promo, atau hal lainnya.

2. Hotel DCF Syariah

Adapun hasil wawancara yang di dapatkan dari adalah sebagai berikut:

a. Adapun fasilitas yang ada untuk para pelanggan Hotel DCF Syariah Syariah adalah, televisi, Ac, Restoran, dan mushalah.

b. Untuk jaringan yang tersedia, di DCF Syariah bekerjasama dengan pihak jaringan seperti Indohome, untuk memblokir situs-situs porno yang ada, sehingga pengunjung tidak dapat mengakses wifi situs porno.

c. Makanan dan minuman yang dijual di Hotel DCF syariah adalah makanan yang halal. Sebab, hotel ini dijalankan sesuai dengan prinsip syariah, dimana dlaam prinsip syariah yang diatur oleh Dewan Syariah Nasional, bahwa hotel yang berbasis syariah tidka boleh menyediakan makanan dna minuman yang haram, tidak boleh menyediakan tempat hiburan yang mengandung pelaksanaan pornografi.

d. Di dalam Standar Organisasi Perusahaan yang ada, kariyawan dan karyawati harus memakai pakaian yang sopan. Karyawati harus mamakai jilbab, dna menggunakan baju yang menutupi aurat. Karyawati juga tidak diperbolehkan menggunakan pakaian yang ketat, dan menampakan auratnya. Customer servis harus mengucapkan salah kepada tamu, dan melayanan tamu sesuai dengan prinsip syariah. Apabila peraturan ini dilanggar, maka karyawan atau karyawati akan mendapat sangsi, baik itu peneguran sampai pada pemecatan.

e. Grand DCF Syariah juga memiliki kerjasama dengan beberapa pihak, seperti traveloka, tike.com, dan Bank Syariah Mandiri. Hal ini dilakukan, untuk mempromosikan Hotel DCF Syariah

3. Hotel SS Syariah

Hotel ini cukup sederhana, bentuk hotelnyapun tidak terlalu besar dan luas, seperti hotel-hotel syariah lainnya. Fasilitas yang ditawarkan oleh hotel 


\section{INTIQAD: JURNAL AGAMA DAN PENDIDIKAN ISLAM}

ISSN 1979-9950 (print) || ISSN 2598-0033 (online), http://jurnal.umsu.ac.id/index.php/intiqad

DOI: https://doi.org/10.30596/intiqad.v10i2.1986

Published December 2018

saudara syariah ini juga tidak banyak seperti hotel lainnya, adapun fasilitas yang ditawarkan adalah, Wifi, AC dan televisi. Untuk wifi, mereka juga memproteks jaringan, sehingga akses internet hanya diperbolehkan untuk mengakses hal-hal yang positif, maka apabila ada konsumen yang mencoba untuk mengakses pornografi, maka jaringan wifi tidak dapat untuk memberikan situs tersbeut.

Hotel SS Syariah ini juga menyediakan mushalah, tetapi mushalah yang diberikannya tentu saja tidak sebesar, mushalah yang ada pada hotel syariah lainnya. Mushalah ini diperuntukan untuk pengunjung dan karyawan hotel. Untuk makanan dan minuman, memang hotel masih mengurus surat sertifikasi halal untuk makanan dan minuman, tetapi sejauh ini mereka juga tetap menjual makanan dan minuman yang halal. Sebab, di dalam peraturan yang berlaku, tidak diperbolehkan atau dikenakan sangsi kariyawan dan pengunjung yang datang, membawa makanan dan minuman yang haram. Hotel SS Syariah ini juga bekerjasama dengan lembaga keuangan syariah, seperti Bank Aceh, dan Bank Syariah Mandiri.

\subsection{Pembahasan}

Dari hasil yang di dapatkan oleh peneliti, terkait dengan operasional hotel syariah yang ada. Maka dengan standart ketentuadn dewan syariah nasional, Nomor 108/DSN-MUI/X/2016. Tentang penyelenggaraan hotel syariah yang ada, harus memenuhi beberapa krikteria, adapun krikteria yang ada, adalah sebagai berikut :

1. Hotel syariah tidak boleh menyediakan fasilitas akses pornografi dan tindakan asusila;

2. Hotel syariah tidak boleh menyediakan fasilitas hiburan yang mengarah pada kemusyrikan, maksiat, pornografi dan/atau tindak asusila;

3. Makanan dan minuman yang disediakan hotel syariah wajib telah mendapat sertifikat halal dari MUI;

4. Menyediakan fasilitas, peralatan dan sarana yang memadai untuk pelaksanaan ibadah, termasuk fasilitas bersuci;

5. Pengelola dan karyawan/karyawati hotel wajib mengenakan pakaian yang sesuai dengan syariah;

6. Hotel syariah wajib memiliki pedoman dan/atau panduan 


\section{INTIQAD: JURNAL AGAMA DAN PENDIDIKAN ISLAM}

ISSN 1979-9950 (print) || ISSN 2598-0033 (online), http://jurnal.umsu.ac.id/index.php/intiqad

DOI: https://doi.org/10.30596/intiqad.v10i2.1986

Published December 2018

mengenai prosedur pelayanan hotel guna menjamin terselenggaranya pelayanan hotel yang sesuai dengan prinsip syariah;

7. Hotel syariah wajib menggunakan jasa Lembaga Keuangan Syariah dalam melakukan pelayanan.

Dari ketentuan yang baku kan oleh dewan syariah nasional, kita dapat melihat, bahwa hotel syariah yang ada di kota medan, memang sudha menerapkan standart apa yang telah diatur oleh dewan syariah. Hal ini didapat oleh peneliti dengan sistem wawancara, tetapi pada hotel Saudara Syariah, pengurusan sertifikasi halal masih berjalan, untuk makanan yang disediakan oleh hotel dan cafe yang ada di dalam hotel. Maka untuk itu, sertifikasi halal belum di dapat oleh hotel saudara syariah.

Untuk mengenai akses pornografi, memang semua hotel syariah menggunakan fasilitas wifi, hanya saja wifi yang di khawatirkan dapat menjadi pintu masuknya pornograti, kini di protek dengan jaringannya sendiri. Hal inilah yang tentunya dapat menjadi contoh oleh siapapun yang ingin menegakan sistem syariah, maka apabila ada akses wifi, seharunya ada sistem pemprotekan wifi, sehingga wifi yang digunakan hanya untuk hal-hal yang positif saja. Hotel syariah juga tidak menyediakan fasilitas yang berbau pornografi, atau tindak asusila, sepeti hiburan, dan lain sebagainya.

Di dalam pelayanan, setiap hotel syariah memang mewajibkan kariyawannya untuk memakai pakaian yang sesuai dengan prinsip syariah, seperti mengenakan jilbab bagi yang wanita. Di dalam hotel syariah, juga mewajibkan kariyawannya untuk melaksanakan shalat, pelaksanaan yang dilaksanakan tentu saja secara bergantian, agar tamu operasional hotel terus berlangsung. Hotel syariah juga memiliki kerjasama dengan lembaga keuangan syariah yang ada di kota Medan, hal ini bertujuan untuk mempromosikan hotel mereka, dna tentu saja juga memenuhi kewajiban, sebgaaimana yang diatur dalam dewan syariah, bahwa penyelenggara hotel syariah wajib bekerjasama dengan lembaga keuangan syariah.

Melihat dari data yang di dapat, atau dari hasil wawancara dan observasi, bahwa hotel syariah yang ada di kota medan memang sudha memenuhi standart yang telah diatur oleh dewan syariah nasional. Hanya saja, apabila 


\section{INTIQAD: JURNAL AGAMA DAN PENDIDIKAN ISLAM}

ISSN 1979-9950 (print) || ISSN 2598-0033 (online), http://jurnal.umsu.ac.id/index.php/intiqad

DOI: https://doi.org/10.30596/intiqad.v10i2.1986

Published December 2018

dewan syariah nasional sudah membuat peraturan yang diberlakukan untuk hotel, maka dewan syariah juga perlu membentuk dewan pengawas syariah, yang tentunya bertujuan untuk, mengawasi hotel-hotel syariah yang ada beroperasi di Indonesia, khususnya di kota Medan. Adanya dewan pengawas hotel syariah, diharapkan hotel tersebut dapat terus kosisten dalam menjalani sistem syariah yang berlaku pada hotel tersebut.

\section{E. Penutup}

Jika dilihat dari pembahasan yang ada di atas, dna penelitian yang dilakukan oleh peneliti. Hotel syariah yang ada di Kota Medan sudah memenuhi persyaratan atau memenuhi peraturan yang telah di keluarkan oleh Dewan Syariah Nasional, tentang penyelenggaraan wisata halal yang ada di Indonesia. Tetapi ketika peneliti melakukan penelitian tersebut, peneliti masih banyak menemukan kejanggalan yang terjadi, seperti kurangnya sosialisasi dewan syariah terhadap peraturan yang telah dibakukan. Jadi ketika peneliti menanyakan tentang peraturan DSN, banyak penyelenggara yang amsih belum mengetahui, dan mereka hanya melihat peraturan atau referensi pendirian hotel syariah dari internet. Maka dari itu, seharusnya DSN mensosialisasikan tentang peraturan yang dibuat, sehingga penyelenggara wisata syariah tidak tabu lagi terhadap peraturan yang ada.

\section{Daftar Pustaka}

AL-Quran dan Terjemahan, Departemen Agama

Ayyub, Syaikh Hassan. (2002). .Edisi Indonesia: Fikih Indonesia.

Jakarta: Pustaka Al-Kautsar

Bagyono, Ludfi Urbani. (2003). Dasardasar Housekeeping dan Loundry Hotel. Yogyakarta: Adicita Karya Nusa.

Fatwa MUI No.108/DSN-MUI/X/2016.

Tentang Wisata Halal

Gajahmada University.

Komar, Richard. (2006). Hotel Managament. Jakarta: Grasindo.

Miles, M.B., \& Huberman, A, M. (1994).

Qualitative Data Analysis: A Sourcebook of New Methods. Thousand Oaks, CA: Sa.

MPPT. No. KM 34/Hk 103/MPPT-87 tentang pengertian Hotel 


\section{INTIQAD: JURNAL AGAMA DAN PENDIDIKAN ISLAM}

ISSN 1979-9950 (print) || ISSN 2598-0033 (online), http://jurnal.umsu.ac.id/index.php/intiqad

DOI: https://doi.org/10.30596/intiqad.v10i2.1986

Published December 2018

Nawawi, Hadari \& Martini, Mimi. Spradley, J.P. (1980). Participant (1994). “Penelitian Terapan”, Observation. Holt Rinehard \& Yogyakarta:

Poerwandari, E. K. (1998). Pendekatan Kualitatif Dalam penelitian UU. No.10. Tahun 2009 tentang Psikologi. Jakarta: Lembaga Pengembangan Sarana Pengukuran pariwisata dan Pendidikan Yin, Robert K. (2014). Studi Kasus Desain \& Metode, Rajawali Pers, Jakarta.

Prabowo. (1996). Memahami Penelitian

Kualitatif. Yogyakarta: Andi

Offset

SKMPRI. No. PM 10/PW-301/Phb.77

tentang pengertian hotel 